\title{
Risks and Benefits of Food Additives - Review
}

\author{
Claudia PAȘCA ${ }^{1 *}$, Aurelia COROIAN ${ }^{1}$, Sonia SOCACI ${ }^{2}$ \\ ${ }^{1}$ Faculty of Animal Science and Biotechnologies. University of Agricultural Sciences and Veterinary \\ Medicine. Romania \\ ${ }^{2}$ Faculty of Food Science and Technology. University of Agricultural Sciences and Veterinary Medicine. \\ Romania \\ *Corresponding author, e-mail: claudia.pasca@usamvcluj.ro
}

Bulletin UASVM Animal Science and Biotechnologies 75(2)/ 2018

Print ISSN 1843-5262; Electronic ISSN 1843-536X

DOI:10.15835/buasvmcn-asb: 2018.0026

\begin{abstract}
Food additives are substances of natural or synthetic origin, which are added to foods to serve a certain technological or sensory function, for example, to counter food perishability and bacterial degradation, give or restore color or impart flavor to foods. These additives generally provide some type of benefit for the food producer, processor or consumer. For example: acids that may be added to prevent the growth of microorganisms that cause spoilage may also prevent the growth of microorganisms that can cause foodborne illness. Some additives are directly added to food and ingredients, while others are added indirectly through contact with packaging materials as are, for example the preservatives BHA and BHT on the inside of breakfast cereal bags.

The benefit of some food additives is enhancing health status or prevents disease; most benefits reflect economic considerations for food processors and sensory attributes and convenience for consumer.
\end{abstract}

Keywords: artificial food additives, benefits, hazards, natural additives

\section{INTRODUCTION}

The safety or risk evaluation of food additives, residues of pesticides and veterinary drugs, and foodcontaminantsisbased on hazardidentification, hazard characterization and assessment of exposure (Kuiper et al., 2001). FAO/WHO and the International Program on Chemical Safety (IPCS) have developed strategies for the safety evaluation of these types of chemicals which may be present in food (WHO, 1987; WHO, 1990). The concept of food safety excluded elements of nutrition, such as: anti-nutrients, toxicants, contaminants and other potentially dangerous elements (dioxin, E.coli) components that are known risk factors for certain chronic diseases (FAO, 2005c) and nutrients in the form of additives, functional foods and supplements. After that, requests have been made at international forums to include these elements in risk and safety activities (FAO/WHO, 2006; Burlingame B., 2001b).

Within the EU, food additives are divided into many functional classes, depending on their function in food: sweeteners, colorants, preservatives, antioxidants, carriers, acids, acidity regulators, anticaking agents, antifoaming agents, bulking agents, emulsifiers, emulsifying salts, firming agents, flavor enhancers, foaming agents, gelling agents, glazing agents, humectants, modified starches, packaging gases, propellants, raising agents, sequestrants, stabilizers, thickeners, and flour treatment agents (Council Regulation (EC) 1333/2008).

The Codex Alimentarius defines a food additive as "any substance not normally consumed as a food itself and not normally used as a typical ingredient of the food, whether or not it has nutritive value, the intentional addition of which to food for a 
technological (including organoleptic) purpose in the manufacture, processing, preparation treatment, packing, packaging, transport or holding of such food results, or may be reasonably expected to result, (directly or indirectly) in it or its by-products becoming a component of or otherwise affecting the characteristics of such foods. The term does not include contaminants, or substances added to food for maintaining or improving nutritional qualities, or sodium chloride" (Codex Alimentarius; Motarjemi et al., 2014; Carocho et al., 2015).

Since 2010, European Commission Regulation and EFSA have started a program to re-evaluate all the existing approved food aditives (Carocho et al., 2014). The $1^{\text {st }}$ evaluation includes food colorants and preservatives (including antimicrobials and antioxidants), which has to be concluded before 2015 . The $2^{\text {nd }}$ group to be evaluated, comprising texturizing agents (including emulsifiers, stablizers and gelling agents) by 2018 , and the last group, sweeteners, to be revised until 2020 (Lodi et al., 2011).

Other research demonstrated that factors such as whether the risk is perceived to be involuntary, unnatural or potentially catastrophic, and whether the risk may affect health rather than the environment, drive public risk perception (Gaskell, 2005; Siegrist et al., 2007b; Rollin et al., 2011). Acceptance of a technology is also partly driven by perception of the potential benefits (Ronteltap et al., 2007). A lack of perceived benefits leads the majority of people to question the need for, and usefulness of, novel food technologies, and may even accentuate perceived risks and moral concerns (Gaskell, 2005).

Despite the various classes of additives, Carocho et al. mentioned in 2014 that the additives can be divided in four fundamental groups with regard to their origin and manufacture: natural additives (obtained directly from animals and plants); similar to natural additives (produced synthetically imitating natural ones); modified from natural (natural additives that are then modified chemically) and finally artificial additives (synthetic compounds).

This bibliographic study aims to present a brief review of the most important scientific findings and research regarding risks and benefits of certain classes of food additives.

\section{PRESERVATIVES}

European Food Safety Authority (EFSA) has issued a scientific opinion on the safety of: ascobyl palmitate (E304), tocopherol-rich extract (E306), $\alpha$-tocopherol (E307), $\gamma$-tocopherol (E308), $\delta$-tocopherol (E309), lecithins (E322), when used as food additive for some food categories like infants below 16 weeks of age, and now the European Commission has asked EFSA to reevaluate these additives. The $\mathrm{E}$ numbers of the preservatives range from E200 to E399. The antimicrobials are added to food for two purposes: to control natural spoilage of food and/or to avoid /control contamination by microorganisms, including pathogenic ones (of food safety concern) (Tajkarimi et al., 2010). Among the most used antimicrobial additives are benzoic acid and benzoates (E210-E219; ADI $5 \mathrm{mg} / \mathrm{kg} \mathrm{bw}$ ), sorbic acid and sorbates (E200-E209; ADI $25 \mathrm{mg} / \mathrm{kg}$ bw); propionic acid and propionates (E280-E289; quantum satis), nitrites (potassium nitrite E249; ADI $0.07 \mathrm{mg} / \mathrm{kg}$ bw, sodium nitrate E250; ADI $0.1 \mathrm{mg} / \mathrm{kg} \mathrm{bw}$ ), nitates (sodium nitrate E251 and potassium nitrate E252; both with ADI $3.7 \mathrm{mg} /$ $\mathrm{kg} \mathrm{bw}$ ), and parabens (E214-E219; ADI $10 \mathrm{mg} / \mathrm{kg}$ bw) table 1 (Carocho et al., 2014).

Nitrites and nitrates are widely used as preservatives in processed meats (eg. frankfurters, salami). These agents have not been associated with hypersensitivity reactions, but can provoke vascular headache; their metabolic products (nitrosamines) are known carcinogens (Simon, 2003).

Sodium benzoate is a closely related substance and may cross-react with other parabens. There has been only one subject reported in the medical literature to be benzoate sensitive, in a doublebind, placebo-controlled study of additiveprovoked asthma (Flynn et al., 1992); this patient was not aspirin-sensitive and did not experience amelioration of asthma symptoms while on a benzoate-free diet (Simon, 2003).

Benzoic acid produced by oxidation of toluene, is a widespread antimicrobial agent, employed against yeast, bacteria and fungi. It acts through membrane distruption and inhibition of metabolic reactions, stress and accumulation of toxic aninons inside the microbial cell (Brul and Coote, 1999; Carocho et al., 2014).

Some in vitro studies have related the conjugated double bonds present in sorbic acid's structure as being prone to nucleophilic attack, turning 
Table 1. Antimicrobial food additives with their ADI quantities (mg/kg bw) (Carocho et al., 2014)

\begin{tabular}{|c|c|c|c|}
\hline Name & E number & ADI & Legislation \\
\hline Benzoic acid & E210 & $5 \mathrm{mg} / \mathrm{kg} \mathrm{bw}$ & $\begin{array}{c}\text { Code of Federal Regulations } 21 \text { Sec.184.1021 } \\
\text { EU Regulation No. 1129/2011 }\end{array}$ \\
\hline Sodium benzoate & E211 & $5 \mathrm{mg} / \mathrm{kg}$ bw & $\begin{array}{c}\text { Code of Federal Regulations } 21 \text { Sec.184.1733 } \\
\text { EU Regulation No. 1129/2011 }\end{array}$ \\
\hline $\begin{array}{l}\text { Ethyl-p-hydroxy- } \\
\text { benzoate (paraben) }\end{array}$ & E214 & $10 \mathrm{mg} / \mathrm{kg} \mathrm{bw}$ & $\begin{array}{c}\text { Code of Federal Regulations 21 Sec.175.105 } \\
\text { EU Regulation No. 1129/2011 }\end{array}$ \\
\hline $\begin{array}{c}\text { Sodium ethyl } \\
\text { p-hydroxybenzoate } \\
\text { (parabens) }\end{array}$ & E215 & $10 \mathrm{mg} / \mathrm{kg} \mathrm{bw}$ & $\begin{array}{c}\text { Code of Federal Regulations 21 Sec.175.105 } \\
\text { EU Regulation No. 1129/2011 }\end{array}$ \\
\hline $\begin{array}{l}\text { Methyl } \\
\text { p-hydroxybenzoate } \\
\text { (parabens) }\end{array}$ & E218 & $10 \mathrm{mg} / \mathrm{kg} \mathrm{bw}$ & $\begin{array}{c}\text { Code of Federal Regulations } 21 \text { Sec.150.141 } \\
\text { EU Regulation No. 1129/2011 }\end{array}$ \\
\hline $\begin{array}{l}\text { Sodium methyl } \\
\text { p-hydroxybenzoate } \\
\text { (paraben) }\end{array}$ & E219 & $10 \mathrm{mg} / \mathrm{kg} \mathrm{bw}$ & $\begin{array}{l}\text { Banned in the United States } \\
\text { EU Regulation No. 1129/2011 }\end{array}$ \\
\hline Sorbic acid & E200 & $25 \mathrm{mg} / \mathrm{kg} \mathrm{bw}$ & $\begin{array}{c}\text { Code of Federal Regulations } 21 \text { Sec.182.3089 } \\
\text { EU Regulation No. 1129/2011 }\end{array}$ \\
\hline Sodium sorbate & E201 & $25 \mathrm{mg} / \mathrm{kg}$ bw & $\begin{array}{l}\text { Code of Federal Regulations } 21 \text { Sec.182.3089- } \\
\text { Not approved in the EU }\end{array}$ \\
\hline Potassium sorbate & E202 & $25 \mathrm{mg} / \mathrm{kg}$ bw & $\begin{array}{c}\text { Code of Federal Regulations } 21 \text { Sec.182.3640 } \\
\text { EU Regulation No. 1129/2011 }\end{array}$ \\
\hline Sulfites & E220-E228 & $0.7 \mathrm{mg} / \mathrm{kg}$ & $\begin{array}{c}\text { Code of Federal Regulations } 21 \text { Sec.182.3616, } \\
\text { 3637, 3739, 3766, } 3798 \\
\text { EU Regulation No. 1129/2011 }\end{array}$ \\
\hline Potassium nitrite & E249 & $0.7 \mathrm{mg} / \mathrm{kg}$ bw & $\begin{array}{c}\text { Code of Federal Regulations 21 Sec.172.160 } \\
\text { EU Regulation No. 1129/2011 }\end{array}$ \\
\hline Sodium nitrate & E250 & $0.1 \mathrm{mg} / \mathrm{kg}$ bw & $\begin{array}{c}\text { Code of Federal Regulations } 21 \text { Sec.172.175 } \\
\text { EU Regulation No. 1129/2011 }\end{array}$ \\
\hline Sodium propionate & E281 & Not specified & $\begin{array}{c}\text { Code of Federal Regulations } 21 \text { Sec.184.1784 } \\
\text { EU Regulation No. 1129/2011 }\end{array}$ \\
\hline
\end{tabular}

Note: ADI=acceptable daily intake

it into mutagenic compound. The interaction between sorbic acid and various amines was tested by Ferrand et al. (2000) for mutagenic and genotoxic activities on HeLa cells and plasmid DNA, resulting in negative values, while another study found sodium sorbate toxic toward human peripheral blood lymphocytes at 400 and $800 \mu \mathrm{g} /$ ml (Mamur et al., 2012)

There are not many studies regarding the toxicity of propionic acids or its salts, (sodium propionate, E281), calcium propionate (E282) and potassium propionate (E283), although it has been considerated to suppress, in a dosedependent manner, Th1-type immune response in human peripheral blood mononuclear cells in vitro. Sodium propionate has been stated as inducing abnormalities on the root tips of onion, while calcium propionate has been related to irritability, restlessness, inattention, and sleep disturbance in some children (Dengate and Ruben, 2002; Turkoglu, 2008; Maier et al., 2010; Carocho et al., 2014). 
It has recently been determined that phosphate additives in food may harm the health of persons with normal renal function (Sullivan et al., 2009). This judgment has been made on the basis of large-scale epidemiological studies and is supported by the latest findings of basic research. It was first recognized in patients with renal disease that a high serum phosphate concentration is a major risk factor for elevated cardiovascular and overall mortality (Block et al., 2004; Kestenbaum et al., 2005).

The antioxidants are another subgroup of the preservatives; they prevent the oxidation of molecules by donating a hydrogen atom or an electron, becoming themselves reduced, in the radical form, but contrary to other radicals, antioxidants when in radical form are more stable and do not allow further reactions to take place, therefore preserving the status quo of the system (Carocho and Ferreira, 2013a,b). The most commonly used antioxidants with quantum satis status are: ascorbic acid (E300), sodium ascorbate (E301), calcium ascorbate (E302), fatty acid esters of ascorbic acid (E304), tocopherols (E306), $\alpha$-tocopherol (E307), $\gamma$-tocopherol (E308), $\delta$-tocopherol (E309), lecithins (E322), sodium lactate (E325), potassium lactate (E326), calcium lactate (E327), citric acid (E330), sodium citrate (E331), potassium citrate (E332), calcium citrate (E333), tartaric acid (E334), sodium potassium tartrate (E337), sodium malate (E350), potassium malate (E351), calcium malate (E352), calcium tartrate (E354) and triammonium citrate (E380); Table 2 (Carocho et al., 2014).

They are known to reduce the risk of cancer, heart disease, and diabetes; to inhibit plasma platelet aggregation, cyclooxygenase (COX) activity, and histamine release, as well as to exert antibacterial, antiviral, anti-inflammatory, and anti-allergenic activities (Shahidi and Ambigaipalan, 2015). The benefits towards many of these conditions arise in part through the antioxidant characteristic of phenolics; therefore, it is important to quantify, identify and evaluate their antioxidant activities (Cevallos-Casals and Cisneros-Zevallos, 2010).

Ethoxyquin is a quinolone-based antioxidant that is not permitted to be added to human food, only used in domestic and farm animal feed. This compound has been reported to induce dermatitis in animals and humans, as well as being a promoter of certain types of cancer. (Blaszczyk et al., 2013; EFSA, 2013a,b). BHA and BHT are antioxidants commonly used in break-fast cereals and other grain producys to maintain crispness and prevent rancidity. There is one well-documented report of cronic urticarial, confirmed by double-blind, placebo-controlled challenges, exacerbated by these agents (Goodman, 1990; Simon, 2003).

TBHQ is commercially available as a beige coloured powder and may be used alone or in combination with BHA or BHT at a maximum

Table 2. Antioxidant food additives with their ADI quantities (mg/kg bw) (Carocho et al., 2014)

\begin{tabular}{cccc}
\hline Name & E number & ADI & Legislation \\
\hline Propyl galate (PG) & E310 & $1.4 \mathrm{mg} / \mathrm{kg} \mathrm{bw}$ & $\begin{array}{c}\text { Code of Federal Regulations 21 Sec.184.1660 } \\
\text { EU Regulation No. 1129/2011 }\end{array}$ \\
\hline $\begin{array}{c}\text { tert-butylhydroquinone } \\
\text { (TBHQ) }\end{array}$ & E319 & $0.7 \mathrm{mg} / \mathrm{kg} \mathrm{bw}$ & $\begin{array}{c}\text { Code of Federal Regulations 21 Sec.172185 } \\
\text { EU Regulation No. 1129/2011 }\end{array}$ \\
\hline $\begin{array}{c}\text { Butylated } \\
\text { hydroxyanisole (BHA) }\end{array}$ & E320 & $0.5 \mathrm{mg} / \mathrm{kg} \mathrm{bw}$ & $\begin{array}{c}\text { Code of Federal Regulations 21 Sec.175.110 } \\
\text { EU Regulation No. 1129/2011 }\end{array}$ \\
\hline $\begin{array}{c}\text { Butylated } \\
\text { hydroxytoluene (BHT) }\end{array}$ & E321 & $0.05 \mathrm{mg} / \mathrm{kg} \mathrm{bw}$ & $\begin{array}{c}\text { Code of Federal Regulations 21 Sec.175.115 } \\
\text { EU Regulation No. 1129/2011 }\end{array}$ \\
\hline $\begin{array}{c}\text { Ethoxyquin (EQ) } \\
\text { E2 }\end{array}$ & E24 & $0.005 \mathrm{mg} / \mathrm{kg} \mathrm{bw}$ & $\begin{array}{c}\text { Code of Federal Regulations 21 Sec.172.140 } \\
\text { EU Regulation No. 1129/2011 }\end{array}$ \\
\hline
\end{tabular}

Note: ADI=acceptable daily intake 
concentration of $0.02 \%$ or $200 \mathrm{ppm}$, based on the fat content of foods, including essential oils (Shahidi and Naczk, 2004). Khan and Shahidi (2001) reported that amongst synthetic antioxidants,TBHQ was more effective than BHA and BHT and served as the strongest antioxidant in borage and evening primrose oil triacylglycerols (TAG). Anothers studies have shown that TBHQ causes DNA cleavage in vitro and the formation of 8-hydroxydeoxyguanosine in calf thymus DNA due to the generation of ROS such as superoxide radical anion and hydrogen peroxide (Shahidi and Ambigaipalan, 2015). In 2009, Han and Park demonstrated that PG inhibits the growth of microorganisms by inhibiting respiration and nucleic acid synthesis; it also decreases hepatic microsomal hydrolase and demethylase activities and inhibits the activity of some redox enzymes. So, in 2015 studies shown that the antioxidative and cytoprotective propertiesof propyl gallate may change to prooxidative, cytotoxic and genotoxic in the presence of $\mathrm{Cu}(\mathrm{II})$.

\section{NATURAL ANTIMICROBIALS}

Natural antimicrobials that can be added to food (but are not considered additives in the sense of Codex Alimentarius definition) are mainly terpens (carvacrol, thymol and menthol), peptides, polysaccharides, and phenlolic compounds. Also in 2014, Abbaszadeh et al., used various compounds from essential oils as alternative agents to control the growth of food-relevant fungi. They shown that the MICs of thymol ranged from 100 to 500 $\mathrm{mg} / \mathrm{mL}$ (mean value: $263.3 \mathrm{mg} / \mathrm{mL}$ ) for different fungal isolates. The most growth inhibition was associated with Cladosporium spp., followed by Aspergillus spp., Fusarium oxysporum, Botrytis cinerea, Penicillium spp., Alternaria alternata and Rhizopus oryzae. For carvacrol the MICs ranged from 50 to $350 \mathrm{mg} / \mathrm{mL}$ (mean value: $154.5 \mathrm{mg}$ / $\mathrm{mL}$ ) for tested fungi, and growth inhibition of Aspergillus spp. was higher than that of other fungal isolates. Generaly, the antifungal effect of thymol was higher than that of carvacrol according to some previous reports (Numpaque et al., 2011). Perez-Alfonso et al. (2012) indicated that both thymol and carvacrol were effective in inhibiting fungal growth, with the predominant efficacy by thymol. The World Health Organization (WHO) has stated that thymol and carvacrol residues in food are without danger to the consumer as long as they do not exceed $50 \mathrm{mg} / \mathrm{kg}$ (WHO, 2002; WHO, 2012).

Eugenol $\left(\mathrm{C}_{10} \mathrm{H}_{12} \mathrm{O}_{2}\right)$ is a clear to pale yellow oil extracted as a major component (approximately 85\%) from buds and leaves of clove (Abbaszadeh et al., 2014). According to previous studies (Wang et al., 2005; Yen et al., 2008), eugenol has been demonstrated as an excellent fungicide against foodborne pathogens. Campanniello et al. (2011) found that eugenol at concentrations of 100$150 \mathrm{mg} / \mathrm{mL}$ is an effective antifungal compound against phytopathogenic Aspergillus, Penicillium, Emericella, and Fusarium species.

The most potent inhibitory activity of menthol was found for Cladosporium spp. and Aspergillus spp., followed by Fusarium oxysporum, Penicillium spp., Rhizopus oryzae, Botrytis cinerea and Alternaria alternata. MIC values for menthol $\left(\mathrm{C}_{10} \mathrm{H}_{20} \mathrm{O}\right)$ ranged from 100 to $450 \mathrm{mg} / \mathrm{mL}$ (mean value: $211.4 \mathrm{mg} / \mathrm{mL}$ ) (Abbaszadeh et al., 2014).

In conclusion, the naturally occurring compounds, such as thymol, carvacrol, eugenol and menthol, showed toxic effects in vitro on fungal growth of all fungal species but different levels of potency.

\section{NATURAL ANTIOXIDANTS}

Antioxidants present in plants, algae, and mushrooms are excellent natural addtitives such as: $\alpha$-tocopherol (E307), $\gamma$-tocopherol (E308), $\delta$-tocopherol (E309), xanthan gum (E415), pectin (E440i) should be added to food stuffs for their iron on hydrogen donating, metal chelating, and chain breaking capabilities. Also, the most antioxidant natural molecules are vitamins, polyphenols, and carotenoids (Ferreira et al., 2009; Carocho et al., 2014). The main foods where antioxidants are used are meats, oils, fried foods, dressings, dairy products, baked goods and extruded snacks (Baines and Seal, 2012). Polyphenols are some of the most interesting groups of natural compounds in the vegetable kingdom, and due to their strong antioxidant capacity they display interesting effects towards human health, namely against cancer, osteoporosis, cataracts, cardiovascular dysfunctions, brain diseases, and immunological conditions (Carocho \& Ferreira, 2013). In another study Carocho et al. (2015) reported that use carotenes, ascorbic acid or vitamin E (tocopherols) are used to benefit from synergies. Carotene mixes and b-carotene have been reviewed by the EFSA's 
scientific panel and ruled out any toxicity arising from its consumption, whether from synthetic provenance or extraction from plants and fruits. Carotenoids are also known for their antioxidant potential as food additives, although their use is always limited by being very susceptibility to oxidation by light. In the same year, the EFSA gathered a scientific opinion regarding ascorbic acid and determined there was no risk in its consumption, not defining an ADI (Baines and Seal, 2012; EFSA, 2015a).

\section{ANTIBROWNING AGENTS}

Enzymatic browning of raw fruits and vegetables is a PPO-catalyzedoxidation reaction leading to the formation of polymerized darkcolored pigments from oxidation of $o$-quinones, which can significantly affect the functional, nutritional, and organoleptic properties of the product (Mogol et al., 2010). There are some chemical compounds for inhibiting PPO activity. The most widely studied compounds are halide salts, carboxylic, and other organic acids, as well as chelating agents that act on the enzyme. In addition, others are mainly reducing agents, including ascorbic acid and its derivatives, SHcompounds, and sulfites, which act on the reaction products through $o$-quinones reduction to $o$-diphenols (their precursors), and formation of colorless compounds by reacting with $o$-quinones (Billaud et al., 2003; Nooshkam et al., 2019).

The different mechanisms for antioxidant potency of MRPs like metal chelation, scavenging of free radicals, breakdown of hydrogen peroxide, and radical chains have been proposed by the

Table 3. Azo-compounds and triarylmethane compounds of dyes with their ADI quantities $(\mathrm{mg} / \mathrm{kg} \mathrm{bw})$ (Carocho et al., 2014)

\begin{tabular}{|c|c|c|c|}
\hline Name & E number & ADI & Legislation \\
\hline $\begin{array}{l}\text { Tartrazine-FD\&C } \\
\text { Yellow No.5. }\end{array}$ & E102 & $7.5 \mathrm{mg} / \mathrm{kg}$ bw & $\begin{array}{c}\text { Code of Federal Regulations 21 Sec.74.1705 } \\
\text { EU Regulation No. 1129/2011 }\end{array}$ \\
\hline $\begin{array}{l}\text { Sunset yellow- } \\
\text { FD\&C Yellow No.6. }\end{array}$ & E110 & $2.5 \mathrm{mg} / \mathrm{kg}$ bw & $\begin{array}{c}\text { Code of Federal Regulations } 21 \text { Sec.74.1706 } \\
\text { EU Regulation No. } 1129 / 2011\end{array}$ \\
\hline Carmoisine & E122 & $4 \mathrm{mg} / \mathrm{kg} \mathrm{bw}$ & $\begin{array}{c}\text { No permission sought in the United States } \\
\text { EU Regulation No. } 1129 / 2011\end{array}$ \\
\hline Amaranth & E123 & $0.8 \mathrm{mg} / \mathrm{kg}$ bw & $\begin{array}{l}\text { Banned in the United States } \\
\text { EU Regulation No. } 1129 / 2011\end{array}$ \\
\hline $\begin{array}{l}\text { Allura red-FD\&C } \\
\text { Red No.40 }\end{array}$ & E129 & $7 \mathrm{mg} / \mathrm{kg}$ bw & $\begin{array}{c}\text { Code of Federal Regulations } 21 \text { Sec.74.340 } \\
\text { EU Regulation No. 1129/2011 }\end{array}$ \\
\hline Patent blue & E131 & $15 \mathrm{mg} / \mathrm{kg} \mathrm{bw}$ & $\begin{array}{l}\text { Banned in the United States } \\
\text { EU Regulation No. } 1129 / 2011\end{array}$ \\
\hline $\begin{array}{l}\text { Brilliant blue- } \\
\text { FD\&C Blue No.1. }\end{array}$ & E133 & $10 \mathrm{mg} / \mathrm{kg} \mathrm{bw}$ & $\begin{array}{c}\text { Code of Federal Regulations 21 Sec.74.101 } \\
\text { EU Regulation No. 1129/2011 }\end{array}$ \\
\hline Brilliant green & E142 & $5 \mathrm{mg} / \mathrm{kg}$ bw & $\begin{array}{c}\text { No permission sought in the United States } \\
\text { EU Regulation No. } 1129 / 2011\end{array}$ \\
\hline $\begin{array}{l}\text { Fast green-FD\&C } \\
\text { Green No.3. }\end{array}$ & E143 & $25 \mathrm{mg} / \mathrm{kg} \mathrm{bw}$ & $\begin{array}{l}\text { Code of Federal Regulations } 21 \text { Sec.74.203- } \\
\text { Banned in the EU }\end{array}$ \\
\hline Brilliant black & E151 & $5 \mathrm{mg} / \mathrm{kg} \mathrm{bw}$ & $\begin{array}{c}\text { No permission sought in the United States } \\
\text { EU Regulation No. } 1129 / 2011\end{array}$ \\
\hline
\end{tabular}

Note: ADI=acceptable daily intake 
common and available antioxidative assays Additionally, these functional compounds have been successfully applied to improve the oxidative stability of diverse foods such as bakery, pasta, meat, oil, and dairy products. As well, they have potential to be used as antibrowning agents in place of sulfite compounds, to inhibit enzymatic browning in fruits and vegetables. Maillard-type conjugates have some functionality, including improved antioxidant, solubility, and heat stability of proteins over a wide range of temperatures, $\mathrm{pH}$ values, and ionic strengths. They also provide a continuous and viscoelastic layer around oil particles, which make them excellent foodgrade carriers for the controlled release of biologically active compounds (Nooshkam et al., 2019).

\section{COLORING AGENTS}

Coloring agents or food dayes are used to alter or confer colors to food, in order to increase its attractiveness toward consumers. There are 5 groups of coloring agents: the azo compounds, the chinophthalon derivatives of quinolone yellow, the triarylmethane group, xanthenes, and the indigo colorants (Sarikaya et al., 2012); Table 3. The only dye with quantum satis status is calcium carbonate (E170), which confers a white color to food and also, calcicum carbonate (E170) need to be re-evaluated by the European Food Safety Authority (EFSA) intended to be used in foods for infants below 16 weeks of age. And also, calcicum carbonate (E170) need to be re-evaluated by the European Food Safety Authority (EFSA) intended to be used in foods for infants below 16 weeks of age.

Some dyes, like amaranth (E123), carmosine (E122) and others are banned in some countries; for instance, both these compounds are banned in the Unites States and not in the EU, while fast green (FD\&C Green No.3) is forbidden to be used within the EU and legally added to food in the United States (Carocho et al., 2014).

Furthermore, given the low rate of absorption, harm to human health is unlikely. However, in light of new findings, is it necessary to regularly assess potential toxicity of food colorants by regulatory authorities and consequently revise guidelines for their use (Amchova et al., 2015).

In the last decades, an increase in the incidence of allergies and asthma has been observed. Besides the well-known hygiene theory, other factors, such as administration of antioxidant supplements, food preserving agents and colorants, have also been suggested to be correlated with the increase in the incidence of allergies and asthma (Vojdani and Vojdani, 2015). Previous researches shown contradictory results on this topic, as erythrosine was shown to inhibit hematopoietic prostaglandin D2 synthase, which is a member of the glutathione transferases, catalyzing the isomerization of prostaglandin $\mathrm{H} 2$ to prostaglandin $\mathrm{D} 2$. This is a mediator of allergy and inflammation responses and hence could be of therapeutic importance in the treatment of allergy and asthma (Mazari et al., 2015). Furthermore, it was found in other studies that even small doses of azo-dyes absorbed from tattoos were recently suggested to trigger immune responses of the body (Baumler, 2015).

\section{CONCLUSION}

Food additives ensure that food can be delivered around the world maintaining its quality and safety, withoutlossesinan evergrowing competitive market. Their role is becoming more and more important with the increase in consumption of highly processed food due to changing lifestyles of modern citizens. Nevertheless the food additives should be used judiciously according to the legal requirements.

\section{REFERENCES}

1. Abbaszadeh S, Sharifzadeh A, Shokri H, Khosravi AR, Abbaszadeh A,(2014). Antifungal efficacy of thymol, carvacrol, eugenol and menthol as alternative agents to control the growth of food-relevant fungi, Journal de Mycologie Médicale, 24(2): 51-56.

2. Ahmad M, Shahidi KF, (2001). Effects of natural and synthetic antioxidants on the oxidative stability of borage and evening primrose triacylglycerols, Food Chemistry, 75(4):431-437.

3. Amchova P, Kotovola H, Ruda-Kucerova J, (2015). Health safety issues of synthetic food colorants, Regulatory Toxicology and Pharmacology, 73(3):914-922.

4. Baines D, Seal R, (2012). Natural food additives, ingredients and flavourings, Woodhead publishing, 100122.

5. Bäumler W, (2015). Absorption, Distribution, Metabolism and Excretion of Tattoo Colorants and Ingredients in Mouse and Man: The Known and the Unknown, Tattooed Skin and Health. Curr Probl Dermatol. Basel, Karger, 48:176-184.

6. Billaud C, Roux E, Brun S Maraschin C, Nicolas J, (2003). Inhibitory effect of unheated and heated d-glucose, d-fructose and l-cysteine solutions and Maillard reaction product model systems on 
polyphenoloxidase from apple. I. Enzymatic browning and enzyme activity inhibition using spectrophotometric and polarographic methods, Food Chemistry, 81(1):3550.

7. Błaszczyk A, Augustyniak A, Skolimowski J, (2013). Ethoxyquin: an antioxidant used in animal feed. Intl J Food Sci, 1-12.

8. Block GA, Klassen PS, Lazarus JM, Ofsthun N, Lowrie EG, Chertow GM, (2004). Mineral Metabolism, Mortality, and Morbidity in Maintenance Hemodialysis, JASN 15 (8): 2208-2218.

9. Brul S, Coote P, (1999). Preservative agents in foods: mode of action and microbial resistance mechanisms. Intl J Food Microbiol 50:1-17.

10. Burlingame B, (2001b). Analysing the total diet. Journal of Food Composition and Analysis 14 (5):451-452.

11. Carocho M, Barreiro MF, Morales P, Ferreira ICFR, (2014). Adding Molecules to Food, Pros and Cons: A Review on Synthetic and Natural Food Additives,Comprehensive Reviews in Food Science and Food Safety, doi: 10.1111/1541-4337.12065.

12. Carocho M, Ferreira ICFR, (2013a). A review on antioxidants, prooxidants and related controversy: natural and synthetic compounds, screening and analysis methodologies and future perspectives. Food Chem Toxicol 51:15-25.

13. Carocho M, Ferreira ICFR, (2013b). The role of phenolics compounds in the fight against cancer-a review. Anticancer Agents Med Chem 13:1236-58.

14. Carocho M, Morales P, Ferreira ICFR, (2015). Natural food additives: Quo vadis?, Trends in Food Science \& Technology 45:284-295.

15. Cevallos-Casals BA, Cisneros-Zevallos L, (2010). Impact of germination on phenolic content and antioxidant activity of 13 edible seed species. Food Chemistry, 119:14851490.

16. Codex Alimentarius. Available from: www. codexalimentarius.net/ gsfaonline/docs/CXS_192e.pdf Accessed 20.10.2018.

17. Council Regulation (EC) 1333/2008 of 16 December 2008 on food additives. OJ L354/16. Accessed 18.10.2018

18. Dengate S, Ruben A, (2002). Controlled trial of cumulative behavioural effects of a common bread preservative. I Paediatr Child Health 38:373-6.

19. EFSA, (2013a). Reasoned opinion on the review of the existing maximum residue levels (MRLs) for ethoxyquin according to Article 12 of Regulation (EC) No 396/20051; EFSA J 11(5):3231.

20. EFSA, (2013b). Press release. Aspartame: EFSA consults on its first full risk assessment. Available from: http:// www.efsa.europa.eu/en/press/news/ 130108.htm. Accessed 20.10.2018.

21. EFSA, (2015). Scientific Opinion on the risks to public health related to the presence of bisphenol A (BPA) in foodstuffs: Part I-Exposure assessment CEF EFSA - EFSA Journal, 13(1):3978.
22. FAO (2005c). Food Safety, Food Safety Management Systems and Private sector Food Standards. FAO Policy Series (working draft, in progress).

23. FAO/WHO (2006). A Model for Establishing Upper Levels of Intake for Nutrients and Related Substances. Report of a Joint FAO/WHO Technical Workshop on Nutrient Risk Assessment. Geneva: (http://www.who.int/ipcs/ methods/nra/en/index. htmlS; Accessed 21.10.2018.

24. Ferrand C, Marc F, Fritsch P, Cassand P, Blanquat G, (2000). Mutagenicity and genotoxicity of sorbic acid-amine reaction products. Toxicol In Vitro 14:423-8.

25. Ferreira ICFR, Barros L, Abreu RM, (2009). Antioxidants in wild mushrooms. Curr Med Chem 16:1543-60.

26. Flynn JL, Goldstein MM, Triebold KJ, Koller B, Bloom BR, (1992). Major histocompatibility complex class I-restricted $\mathrm{T}$ cells are required for resistance to Mycobacterium tuberculosis infection, PNAS December 15, 89(24):12013-12017.

27. Gaskell G, Eyck T, Jackson TJ, Veltri G, (2005). Imaging nanotechnology: Cultural support for technological innovation in Europe and the United States. Public Understanding of Science, 14:81-90.

28. Golka K, Sondermann R, Reich S, Wiese A, (2004). Carbohydrate-deficient transferrin (CDT) as a biomarker in persons suspected of alcohol abuse, Toxicology Letters, 151(1):235-241.

29. Goodman PL, McDannell JT, Nelson NS, Vaughan TR, Weber RW, Colo MDA, (1990). Chronic urticarial exacerbated by the antioxidant food preservatives butylated hydroxyanisole (BHA) and butylated hydroxytoluene (BHT). J Allergy Clin Immunol 86:570-575.

30. Han YH, Park WH, (2009). Propyl gallate inhibits the growth of HeLa cells via regulating intracellular GSH level, Food and Chemical Toxicology, 47:2531-2538.

31. Kestenbaum B, Sampson JN, Rudser Kyle DP, Donald J, Seliger SL, Young B, Sherrard DJ, Andress DL, (2005). You have access Serum Phosphate Levels and Mortality Risk among People with Chronic Kidney Disease, JASN, 16 (2):520-528.

32. Kuiper HA, Kleter GA, Hub P, Noteborn JM, Kok EJ (2001). Assessment of the food safety issues related to genetically modified foods, The Plant Journal, 27(6):503-528.

33. Lodi F, Gartlon J, Kenigswald GK, (2011). The European Food Safety Authority (EFSA) re-evaluation of EU approved food additives. Toxicol Lett 205:S242-3.

34. Maier E, Kurz K, Jenny M, Schennach H, Ueberall F, Fuchs D, (2010). Food preservatives sodium benzoate and propionic acid and colorant curcumin suppress Th1-type immune response in vitro. Food Chem Toxicol 48:1950-6.

35. Mamur S, Yuzbasioglu D, Unal F, Aksoy H, (2012). Genotoxicity of food preservative sodium sorbate in lymphocytes in vitro. Cytotechnology 64:553-62.

36. Mazari AS, Ali Badrul BS, Mohamed MJ, Nizamuddin $S S$, (2015). An overview of solvent management and emissions of amine-based $\mathrm{CO}_{2}$ capture technology, International Journal of Greenhouse Gas Control 34:129140. 
37. Mogul JC, Tourrilhes J, Yalagandula P, Sharma P, Curtis AR, Banerjee S, (2010). DevoFlow: Cost-Effective Flow Management for High Performance Enterprise Networks, ACM 978-1-4503-0409-2/10/10.

38. Motarjemi Y, Moy G, Todd E, (2014). Encyclopedia of food safety (1st ed.). Missouri, USA: Elsevier.

39. Naczk M, Shahidi F, (2014). Review Extraction and analysis of phenolics in food, Journal of Chromatography A, 1054(1-2):95-111.

40. Nooshkam M, Varidi M, Bashash M, (2019). The Maillard reaction products as food-born antioxidant and antibrowning agents in model and real food systems, Food Chemistry 275: 644-660.

41. Numpaque MA, Oviedo LA, Gil JH, Garcia CM, Durango DL, (2011). Thymol and carvacrol: biotransformation and antifungal activity against the plant pathogenic fungi Colletotricjum acutatumand Botryodiplodia theobromae. Trop Plant Pathol, 36:3-13.

42. Perez-Alfonso CO, Martinez-Romero D, Zapata PJ, Serrano M, Valero D, Castillo S, (2012). The effects of essential oils carvacrol and thymol on growth of Penicillium digitatum and P. italicum involved in lemon decay. Int J Food Microbiol,158:101-6.

43. Ronteltap A, Van Trijp JCM, Renes RJ, Frewer LJ, (2007). Consumer acceptance of technology-based food innovations: lessons for the future of nutrigenomics. Appetite, 49:1-17.

44. Sarikaya R, Sevi M, Erkoc F, (2012). Evaluation of potential genotoxicity of five food dyes using the somatic mutation and recombination test, Chemosphere, 88(8):974-979.

45. Shahidi F, Ambigaipalan P, (2015). Phenolics and polyphenolics in foods, beverages and spices: Antioxidant activity and health effects - A review, Journal of Functional Foods, 18:820-897.

46. Siegrist M, Stampfli N, Kastenholz H, Keller C, (2008). Research report Perceived risks and perceived benefits of different nanotechnology foods and nanotechnology food packaging, Appetite 51:283-290.

47. Simon RA, (2003) Adverse Reactions to Food Additives, Food Allergy, 61-66.

48. Sullivan C, Sayre SS, Leon JB, Machekano R, Love TE, Porter D, Marbury M, Sehgal AR, (2009). Effect of Food Additives on Hyperphosphatemia Among Patients With End-stage Renal Disease A Randomized Controlled Trial, JAMA, 301(6).

49. Tajkarimi MM, Ibrahim SA, Cliver DO, (2010). Review Antimicrobial herb and spice compounds in food, Food Control 21:1199-1218.

50. Turkoglu S, (2008). Evaluation of genotoxic effects of sodium propionate and potassium propionate on the root meristem cells of Allium cepa. Food Chem Toxicol 46:2035-41.

51. Vojdani A, Vojdani C, (2015). Immune reactivity to food coloring, Alternative Therapies, 21(1):1-100.

52. Wang SY, Chen PF, Chang ST, (2005). Antifungal activities of essential oils and their constituents from indigenous cinnamon (Cinnamomum osmophloeum) leaves against wood decay fungi. Bioresour Technol, 96:813-8.

53. WHO, (1987). Principles for the Safety Assessment of Food Additives and Contaminants in Food. Environmental Health Criteria 70. Geneva: World Health Organization.

54. WHO, (1990). Principles for the Toxicological Assessment of Pesticide Residues in Food. Environmental Health Criteria 104. Geneva: World Health Organization.

55. WHO, (2002). Food safety and foodborne illness. World Health Organization Fact sheet 237.

56. WHO, (2012). http://apps.who.int/medicinedocs/en/d/ Js2200e/28. html2012 (accessed 20.10.2018).

57. Yen TB, Chang ST, (2008). Synergistic effects of cinnamaldehyde in combination with eugenol against wood decay fungi. Bioresour Technol, 99:232-6. 